\title{
Modified biochar from Moringa seed powder for the removal of diclofenac from aqueous solution
}

\author{
Afrouz Bagheri $^{1} \cdot$ Emmanuel Abu-Danso $^{1} \cdot$ Jibran Iqbal $^{2}$ (D) $\cdot$ Amit Bhatnagar $^{1}$
}

Received: 29 July 2019 / Accepted: 21 October 2019 /Published online: 28 December 2019

(C) The Author(s) 2019

\begin{abstract}
In this study, Moringa seed powder $\left(\mathrm{M}_{\mathrm{SP}}\right)$ was pyrolyzed at $450{ }^{\circ} \mathrm{C}$ to synthesize Moringa seed powder biochar $\left(\mathrm{M}_{\mathrm{SP}} \mathrm{B}\right)$ and treated with phosphoric acid $\left(\mathrm{H}_{3} \mathrm{PO}_{4}\right)$ to synthesize phosphate-modified Moringa seed powder biochar $\left(\mathrm{M}_{\mathrm{SP}} \mathrm{B}-\mathrm{HPO}\right)$ as an adsorbent for the removal of diclofenac (Dfc) from aqueous solution. Fourier transform infrared (FTIR) analysis, energy dispersive $\mathrm{X}$-ray spectroscopy (EDS), scanning electron microscopy ( $\mathrm{SEM})$, and $\mathrm{pH}$ point of zero charge $\left(\mathrm{pH}_{\mathrm{pzc}}\right)$ were conducted to give more insight into the adsorbent's properties. The SEM analysis showed the transformations in the surface morphology from the parent material to the synthesized materials after the thermal and acid treatment. EDS analysis revealed the variation in the elemental composition of the materials prior to and after adsorption of Dfc ions. The FTIR analysis showed changes and peak intensities of functional groups involved in Dfc removal. The $\mathrm{pH}_{\mathrm{pzc}}$ showed the charge carried by $\mathrm{M}_{\mathrm{SP}} \mathrm{B}-\mathrm{HPO}$ in different $\mathrm{pH}$ conditions. Isotherm data best matched the Sips model, and the pseudo-second-order model best described the adsorption kinetics. The maximum adsorption capacity of $\mathrm{M}_{\mathrm{SP}} \mathrm{B}-\mathrm{HPO}$ by Sips model was found to be $100.876 \mathrm{mg} \mathrm{g}^{-1}$.
\end{abstract}

Keywords Moringa oleifera seed powder $\cdot$ Biochar $\cdot$ Adsorption $\cdot$ Diclofenac $\cdot$ Phosphate modification

\section{Introduction}

According to international scientific statistics, $70 \%$ of accessible fresh water is utilized in agriculture and food industry (Wong et al. 2018). Water demand is increasing, while the quality and quantity of freshwater are continuously decreasing due to anthropogenic activities (Wong et al. 2018; Murtaza et al. 2019). In recent decades, numerous micropollutants including pharmaceuticals have emerged in different environments. Pharmaceutical compounds have found their way into

Responsible editor: Tito Roberto Cadaval Jr

Afrouz Bagheri

bagha@uef.fi

Emmanuel Abu-Danso

emmanuel.abu-danso@uef.fi

Jibran Iqbal

Jibran.Iqbal@zu.ac.ae

1 Department of Environmental and Biological Sciences, University of Eastern Finland, FI-70211 Kuopio, Finland

2 College of Natural and Health Sciences, Zayed University, P.O. Box 144534, Abu Dhabi, United Arab Emirates freshwater resources and consequently, decrease the quality. Diclofenac (Dfc), which is used as an analgesic, is one of the main priorities of emerging contaminants. It requires special treatment due to the noxious effects on environmental health (Moreno et al. 2009; Beyki et al. 2017; Barczak et al. 2018; Li and Yang 2018; Sayed et al. 2019). Removal processes of pharmaceutical contaminants such as photocatalytic degradation, biological treatment, and filtration have been extensively used. These processes have some level of efficiency, but they have their limitations such as extended contact time, high operational, and energy cost. Adsorption, however, has many advantages over the different techniques including vast efficiency, easiness, and low operational cost. In adsorption process, contaminants are adsorbed from the liquid phase to a solid phase (Beyki et al. 2017; Barczak et al. 2018; Li et al. 2018).

Biomass is a significant resource that can be converted to a carbonized biochar, a bio-material that has received wide attention. Biochar is carbon-rich microporous material and has high-value application in water pollution remediation (Jindo et al. 2014). Moringa oleifera is a tropical and subtropical plant species with a good yield of seeds. The other parts such as the leaves have been used as sorbent in various water treatment studies (Maina et al. 2016). The seed husk has also been 
studied in the adsorption of diclofenac (Araujo et al. 2018), acid black 1 and basic red 2, reactive dyes, heavy metals, atrazine, and nitrobenzene from solution (Buildings et al. 1997; Akhtar et al. 2007; de Carvalho et al. 2015; Matouq et al. 2015; Tavengwa et al. 2016; Maina et al. 2016; Souza et al. 2016; Tavares et al. 2017; Coldebella et al. 2017; Khorsand et al. 2017; Maria et al. 2018; Shirani et al. 2018).

In this study, a simple technology was used to prepare phosphate-modified Moringa oleifera seed powder biochar $\left(\mathrm{M}_{\mathrm{SP}} \mathrm{B}-\mathrm{HPO}\right)$ using mild phosphoric acid $(0.5 \mathrm{M})$ as phosphate source and used for the adsorption of diclofenac (Dfc) from water. Moringa oleifera seed powder biochar $\left(\mathrm{M}_{\mathrm{SP}} \mathrm{B}\right)$ was synthesized at $450{ }^{\circ} \mathrm{C}$ in a $\mathrm{N}_{2}$ injection chamber. The prepared biochar was spun in phosphoric acid to synthesize $\mathrm{M}_{\mathrm{SP}} \mathrm{B}-\mathrm{HPO}$ adsorbent. Parameters including effect of $\mathrm{pH}$, initial Dfc concentrations, and contact time on the adsorption of $\mathrm{Dfc}$ by $\mathrm{M}_{\mathrm{SP}} \mathrm{B}-\mathrm{HPO}$ were investigated. Characterization of $\mathrm{M}_{\mathrm{SP}} \mathrm{B}-\mathrm{HPO}$ as well as the adsorption behaviors was studied to evaluate the performance of their practical applications in Dfc removal from water.

\section{Materials and methods}

\section{Chemicals}

Moringa oleifera seeds were obtained commercially. SigmaAldrich (Suomi) supplied sodium chloride $(\mathrm{NaCl} 99 \%)$ and sodium hydroxide (NaOH 98.9\%). Phosphoric acid ( $85 \mathrm{wt} \%$ ) and diclofenac sodium salt $(98.5 \%)$ were purchased from Acros (Geel, Belgium).

\section{Thermal treatment of Moringa seeds powder $\left(M_{S P}\right)$}

The $\mathrm{M}_{\mathrm{SP}} \mathrm{B}$ was produced by thermal pyrolysis. The sample was placed in a crucible and then placed in a fixed-bed stainless steel tubular furnace under $\mathrm{N}_{2}$ atmosphere. The temperature was raised from room temperature to $450{ }^{\circ} \mathrm{C}$ at a heating rate of $10{ }^{\circ} \mathrm{C} / \mathrm{min}$ and sustained for ca. $2 \mathrm{~h}$. The biochar was allowed to cool and then ground and sieved through a $160-\mu \mathrm{m}$ sieve.

\section{Modification of Moringa seeds powder biochar $\left(\mathrm{M}_{\mathrm{SP}} \mathrm{B}\right)$}

An amount of $\mathrm{M}_{\mathrm{SP}} \mathrm{B}$ (ca. $1.5 \mathrm{~g}$ ) was pulverized and mixed with 50-mL $0.5 \mathrm{M}$ phosphoric acid $\left(\mathrm{H}_{3} \mathrm{PO}_{4}\right)$ and spun at $80 \mathrm{rpm}$ speed for $24 \mathrm{~h}$. $\mathrm{M}_{\mathrm{SP}} \mathrm{B}-\mathrm{HPO}$ was washed using deionized water to neutral $\mathrm{pH}$ and dried overnight in an oven at $40^{\circ} \mathrm{C}$.

\section{Characterization}

The surface morphology of $\mathrm{M}_{\mathrm{SP}}$ and the biochars were analyzed with Zeiss sigma HDVP (Carl Zeiss GmbH,
Oberkochen Germany) scanning electron microscopy. Separate voltages and magnifications were chosen to optimize the image. Samples for the analysis were sputtered with gold by using agar auto gold sputter. Elemental composition of the synthesized materials was analyzed with energy-dispersive $\mathrm{X}$ ray spectroscopy (EDS) (Sigma HDVP, Carl Zeiss GmbH, Germany). The Fourier transform infrared (FTIR) analysis of the different materials in this study was recorded between 400 and $4000 \mathrm{~cm}^{-1}$ at 32 scans using Thermo Nicolet Nexus 8700 model (Thermo electron, Madison USA) to examine the changes in functional groups on the synthesized materials, before and after adsorption.

\section{Adsorption experiments}

Batch adsorption experiments were performed to investigate diclofenac adsorption. A solution of $100 \mathrm{mg} \mathrm{L}^{-1}$ (stock) was prepared and covered to prevent photo-degradation. Dilution was used to prepare different concentrations of Dfc (2.5$70 \mathrm{~m} \mathrm{~L} \mathrm{~L}^{-1}$ ) from the stock solution. A predetermined quantity of $\mathrm{M}_{\mathrm{SP}} \mathrm{B}$-HPO and a volume of $40 \mathrm{mg} \mathrm{L}^{-1}$ concentration of $\mathrm{Dfc}(10 \mathrm{~mL})$ at $(\mathrm{pH} \sim 5)$ were both put in capped falcon tubes and were agitated at $80 \mathrm{rpm}$ on a shaker at room temperature until equilibrium time. After equilibration time, $\mathrm{M}_{\mathrm{SP}} \mathrm{B}-\mathrm{HPO}$ was filtered from $D f c$ solution using filters with $0.45 \mu \mathrm{m}$ pore size (Sartorius, Gmbh Germany). The Dfc residual concentrations of all batch adsorption experiments were analyzed with UV-VIS Spectrophotometer (UV-2401 PC (double beam)) at $\lambda_{\max }=287 \mathrm{~nm}$ wavelength. The adsorbed Dfc at equilibrium capacity onto the $\mathrm{M}_{\mathrm{SP}} \mathrm{B}-\mathrm{HPO}$ was analyzed using eq. (1) and the percentage removal efficiency was determined according to eq. (2) (Daneshvar et al. 2012):

$q_{e}=\frac{(C i-C e) V}{m}$

$R(\%)=\frac{(C i-C e)}{C i} \times 100$

where $q_{\mathrm{e}}$ is the adsorption capacity of $\mathrm{M}_{\mathrm{SP}} \mathrm{B}-\mathrm{HPO}\left(\mathrm{mg} \mathrm{g}^{-1}\right), C_{\mathrm{i}}$ and $C_{\mathrm{e}}$ are the initial and final diclofenac concentrations (mg $\left.\mathrm{L}^{-1}\right), v$ is the volume of the diclofenac (L), $m$ is the amount of $\mathrm{M}_{\mathrm{SP}} \mathrm{B}-\mathrm{HPO}(\mathrm{g})$, and $R(\%)$ is the removal efficiency.

\section{Experimental results and discussion}

\section{Scanning electron microscopy analysis}

The microscopic morphological observations of $\mathrm{M}_{\mathrm{SP}}, \mathrm{M}_{\mathrm{SP}} \mathrm{B}$, and $\mathrm{M}_{\mathrm{SP}} \mathrm{B}-\mathrm{HPO}$ are presented in Fig. 1a-c. The micrograph of $\mathrm{M}_{\mathrm{SP}}$ (Fig. 1a) showed a non-uniform complex fiber matrix with no particular shape as reported elsewhere (Tavengwa et al. 2016). However, after the thermal treatment $\left(450{ }^{\circ} \mathrm{C}\right)$ 
in a $\mathrm{N}_{2}$ environment (Fig. 1b), the surface morphology revealed macropores and irregular trough-like patterns. The structure appeared frail and the cell morphology of plant biochar was absent. The phosphate-modified biochar $\left(\mathrm{M}_{\mathrm{SP}} \mathrm{B}\right.$ HPO) revealed trough-like patterns; however, it also showed cup-like cell shapes with embedded macropores (Fig. 1c). Compared to $\mathrm{M}_{\mathrm{SP}} \mathrm{B}, \mathrm{M}_{\mathrm{SP}} \mathrm{B}-\mathrm{HPO}$ showed well-defined edges which suggests further cleaving of the material from the $\mathrm{M}_{\mathrm{SP}} \mathrm{B}$. As seen from Fig. 1c, the chemical modification by $\mathrm{H}_{3} \mathrm{PO}_{4}$ could enhance the specific internal surface area (Chen et al. 2017).

\section{Energy-dispersive X-ray spectroscopy (EDS) analysis}

The elemental composition of the synthesized materials (atomic \%) was analyzed by EDS. As the results illustrate in Table 1, the chemical composition of biochar changes significantly during biomass pyrolysis and the subsequent modification by weak $\mathrm{H}_{3} \mathrm{PO}_{4}$. The EDS results showed that the atomic percentages of $\mathrm{C}$ and $\mathrm{O}$ in the $\mathrm{M}_{\mathrm{SP}}, \mathrm{M}_{\mathrm{SP}} \mathrm{B}-\mathrm{HPO}$ on one hand, and $\mathrm{M}_{\mathrm{SP}} \mathrm{B}-\mathrm{HPO}$ after Dfc adsorption were $73.2 \%$,
$22.2 \% ; 84.9 \%, 8 \% ; 87.3 \%, 8.3 \%$; and $89.8,9.2 \%$, respectively. After thermal induction, the decarboxylation and dehydration of Moringa biomass into $\mathrm{H}_{2} \mathrm{O}, \mathrm{CO}_{2}, \mathrm{CO}$, etc. occurred and a larger amount of $\mathrm{O}$ compared to $\mathrm{C}$ was lost, because electrons during destruction of carbonyl groups move to oxygen and formed radicalized oxygen. In addition, biomass generally contains some removable $\mathrm{O}$ fractions while after pyrolysis, some still remains in the biochar (Harvey et al. 2012; Rutherford et al. 2012; Jindo et al. 2014; Chen et al. 2017). The P content of $\mathrm{M}_{\mathrm{SP}} \mathrm{B}-\mathrm{HPO}$ and $\mathrm{M}_{\mathrm{SP}} \mathrm{B}-\mathrm{HPO}$ after Dfc adsorption was 1.5 and $1.3 \%$, respectively, suggesting that phosphates was successfully etched on $\mathrm{M}_{\mathrm{SP}} \mathrm{B}$.

\section{Point of zero charge $\left(\mathrm{pH}_{\mathrm{pzc}}\right)$ analysis of $\mathrm{M}_{\mathrm{SP}} \mathrm{B}-\mathrm{HPO}$}

The $\mathrm{pH}_{\mathrm{pzc}}$ analysis of $\mathrm{M}_{\mathrm{SP}} \mathrm{B}-\mathrm{HPO}$ was studied from 2 to 10 $\mathrm{pH}$ range and the result is presented in Fig. 2a. The $\mathrm{pH}_{\mathrm{pzc}}$ was found to be 7.09 and the result showed that the $\mathrm{M}_{\mathrm{SP}} \mathrm{B}-\mathrm{HPO}$ has variable electrostatic charges in different $\mathrm{pH}$ conditions. In acidic medium, the material was negatively charged; however, the charge changed to positive when the material was studied
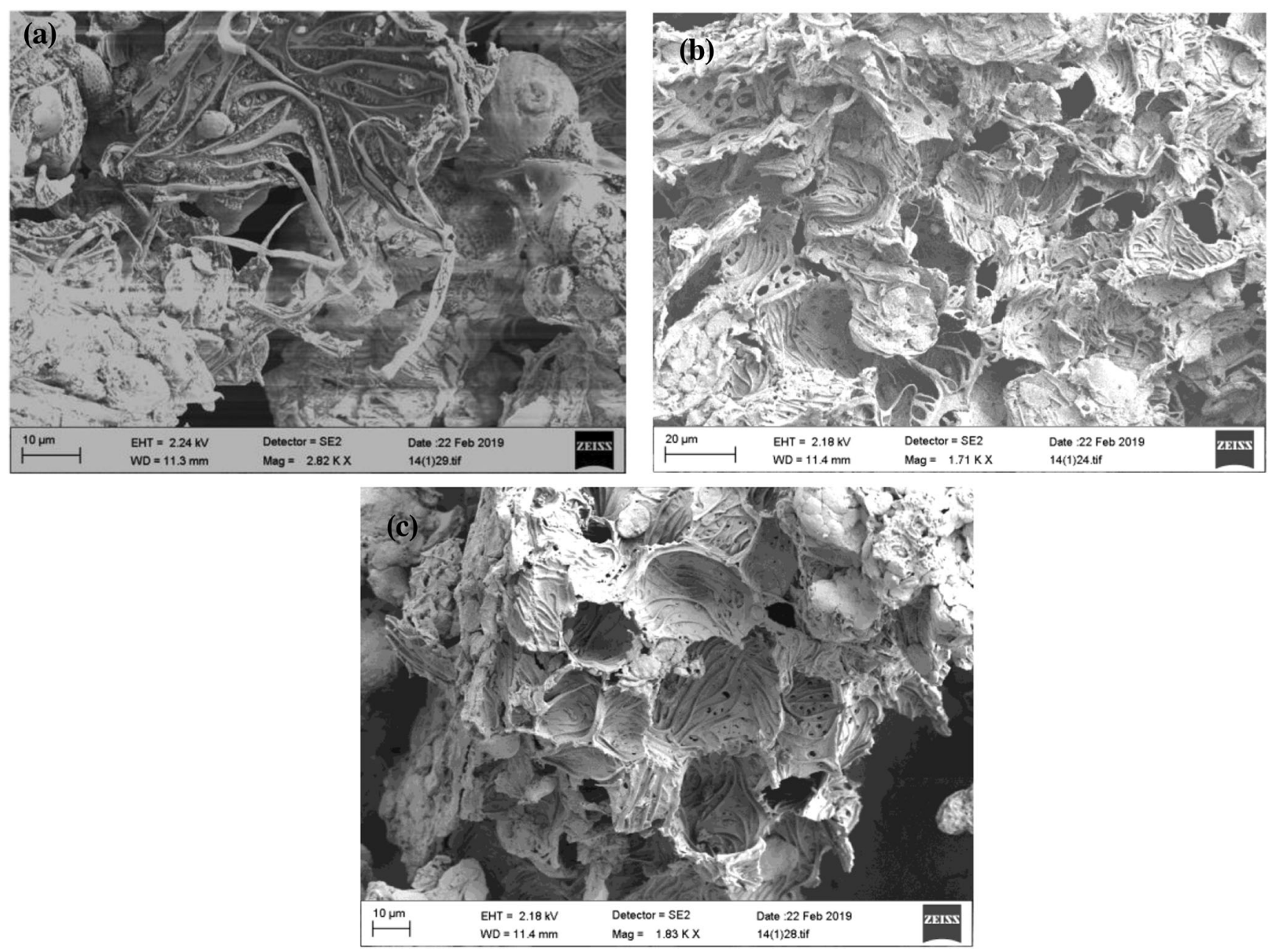

Fig. 1 SEM images of a $M_{S P}$ b $M_{S P} B, \mathbf{c} M_{S P} B-H P O$ 
Table 1 Elemental (atomic \%) analyses of $\mathrm{M}_{\mathrm{SP}}, \mathrm{M}_{\mathrm{SP}} \mathrm{B}, \mathrm{M}_{\mathrm{SP}} \mathrm{B}-\mathrm{HPO}$, and $\mathrm{M}_{\mathrm{SP}} \mathrm{B}-\mathrm{HPO} / \mathrm{Dfc}$

\begin{tabular}{lllll}
\hline Element & $\mathrm{M}_{\mathrm{SP}}$ & $\mathrm{M}_{\mathrm{SP}} \mathrm{B}$ & $\begin{array}{l}\mathrm{M}_{\mathrm{SP}} \mathrm{B}- \\
\mathrm{HPO}\end{array}$ & $\begin{array}{l}\mathrm{M}_{\mathrm{SP}} \mathrm{B}-\mathrm{HPO} / \\
\mathrm{Dfc}\end{array}$ \\
\hline $\mathrm{C}$ & 73.2 & 84.9 & 87.3 & 89.8 \\
$\mathrm{~N}$ & 8.2 & 7 & 7.3 & 9 \\
$\mathrm{O}$ & 22.2 & 8 & 8.3 & 9.2 \\
$\mathrm{P}$ & 0 & 0 & 1.5 & 1.3 \\
$\mathrm{Cl}$ & 0 & 0 & 0 & 0.3 \\
\hline
\end{tabular}

in alkaline medium. This characteristic of $\mathrm{M}_{\mathrm{SP}} \mathrm{B}-\mathrm{HPO}$ suggests that it can have a favorable interaction with a positively charged adsorbate in an acidic medium.

\section{Fourier transform infrared spectroscopy analysis}

The different infrared spectrum of the different materials is presented in Fig. 2b. The main peaks on the $\mathrm{M}_{\mathrm{SP}}$ were found at $\sim 3300,2923$, and $1007 \mathrm{~cm}^{-1}$ which represent $\mathrm{OH},-\mathrm{CH}$, and $-\mathrm{OCH}_{3}$ functional groups, respectively, as found in other study (Ramavandi 2014). The peaks assigned to carbonyl $(\mathrm{C}=\mathrm{O})$ functional groups were found at $\sim 1635, \sim 1700$, and $1735 \mathrm{~cm}^{-1}$ (Ramavandi 2014). The peaks of some aforementioned functional groups shifted after thermal treatment of $\mathrm{M}_{\mathrm{SP}}$. This phenomenon can be attributed to the thermal assisted destruction or conversion of the functional groups. The peak at $\sim 1730 \mathrm{~cm}^{-1}$ shifted on $\mathrm{M}_{\mathrm{SP}} \mathrm{B}$ spectra because $\mathrm{C}=\mathrm{O}$ is easy to be lacerated after heat treatment. After the modification to form $\mathrm{M}_{\mathrm{SP}} \mathrm{B}-\mathrm{HPO}$, two peaks associated with phosphate and carbon interaction appeared, firstly at $\sim 1095 \mathrm{~cm}^{-1}$ assigned to $\mathrm{P}-\mathrm{O}-\mathrm{C}$ stretching vibration mode (Coates et al. 2000); this peak, however, significantly changed after Dfc adsorption. The other peak representing $(\mathrm{P}-\mathrm{O})$ bond at $745-725 \mathrm{~cm}^{-1}$ appeared (Pavia et al. 2009). The FTIR of $\mathrm{M}_{\mathrm{SP}} \mathrm{B}-\mathrm{HPO}$ after Dfc adsorption (Dfc- $\mathrm{M}_{\mathrm{SP}} \mathrm{B}$ ) showed a reduction in the $-\mathrm{P}$ bond after diclofenac adsorption.
Adsorption of diclofenac by $\mathrm{M}_{\mathrm{SP}} \mathrm{B}-\mathrm{HPO}$

\section{Effect of $\mathrm{pH}$ on the adsorption of Dfc by $\mathrm{M}_{\mathrm{sp}} \mathrm{B}-\mathrm{HPO}$}

The influence of $\mathrm{pH}$ on the adsorption of Dfc was investigated in $\mathrm{pH}$ range of $2-10$. To adjust the solution $\mathrm{pH}$, known concentrations of hydrochloric acid and sodium hydroxide were used and the results are shown in Fig. $3 \mathrm{a}$. The results revealed higher adsorption capacities in moderate acidic $\mathrm{pH}$. The highest removal capacity of $95.85 \mathrm{mg} \mathrm{g}^{-1}$ representing $82.8 \%$ removal efficiency was recorded at $\mathrm{pH} \sim 5$. The adsorption capacity decreased sharply beyond $\mathrm{pH} \sim 5$ and the reduction in adsorption capacity continued in basic $\mathrm{pH}$. The significant decrease in the adsorption capacity in basic medium can be attributed to the rapid deprotonation in the system which results in repulsion between the $\mathrm{M}_{\mathrm{SP}} \mathrm{B}-\mathrm{HPO}$ surface thereby preventing complexation of $\mathrm{M}_{\mathrm{SP}} \mathrm{B}-\mathrm{HPO}$ surface and the Dfc ions as reported in other study (Hu and Cheng 2015). During the modification process, phosphates from dissociated $\mathrm{H}_{3} \mathrm{PO}_{4}$ interact with the graphite-like crystallites of the biochar. This interaction results in $\mathrm{P}-\mathrm{O}-\mathrm{C}$ linkages on the modified biochar to form a net negatively charged surface as (Wang et al. 2017). The synthesized $\mathrm{M}_{\mathrm{SP}} \mathrm{B}-\mathrm{HPO}$ as a carbonaceous material is able to adsorb the $\mathrm{pH}$ modified Dfc via $\pi-\pi$ interactions and these interactions are controlled by the changes in $\mathrm{pKa}$ of Dfc because changes in the pKa values can affect Dfc to take on cationic, neutral, or anionic character (Jiang et al. 2015; Lonappan et al. 2018). Furthermore, low-temperature synthesized biochars including $\mathrm{M}_{\mathrm{SP}} \mathrm{B}$ are hydrophobic and adsorb pollutants effectively in an acidic phase (Fig. 4).

\section{Adsorption kinetic modeling}

The influence of contact time on $\mathrm{M}_{\mathrm{SP}} \mathrm{B}$ adsorption of $\mathrm{Dfc}$ ions was performed to obtain data on the overall uptake rate of adsorbate with time (Shirani et al. 2018). The
Fig. 2 a $\mathrm{pH}_{\mathrm{pzc}}$ of $\mathrm{M}_{\mathrm{SP}} \mathrm{B}-\mathrm{HPO}, \mathbf{b}$ FTIR spectra of $\mathrm{M}_{\mathrm{SB}}, \mathrm{M}_{\mathrm{SP}} \mathrm{B}$, $\mathrm{M}_{\mathrm{SP}} \mathrm{B}-\mathrm{HPO}$, and Dfc- $\mathrm{M}_{\mathrm{SP}} \mathrm{B}$

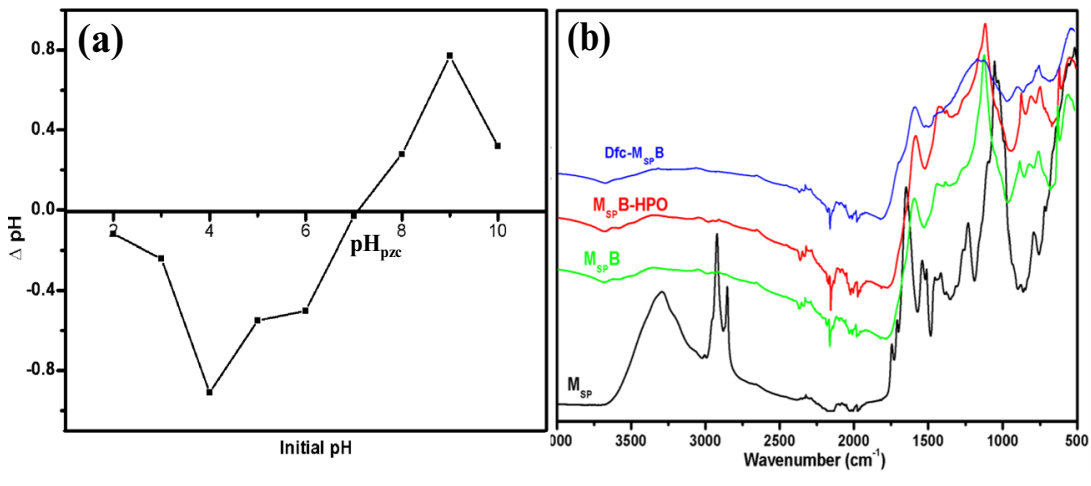



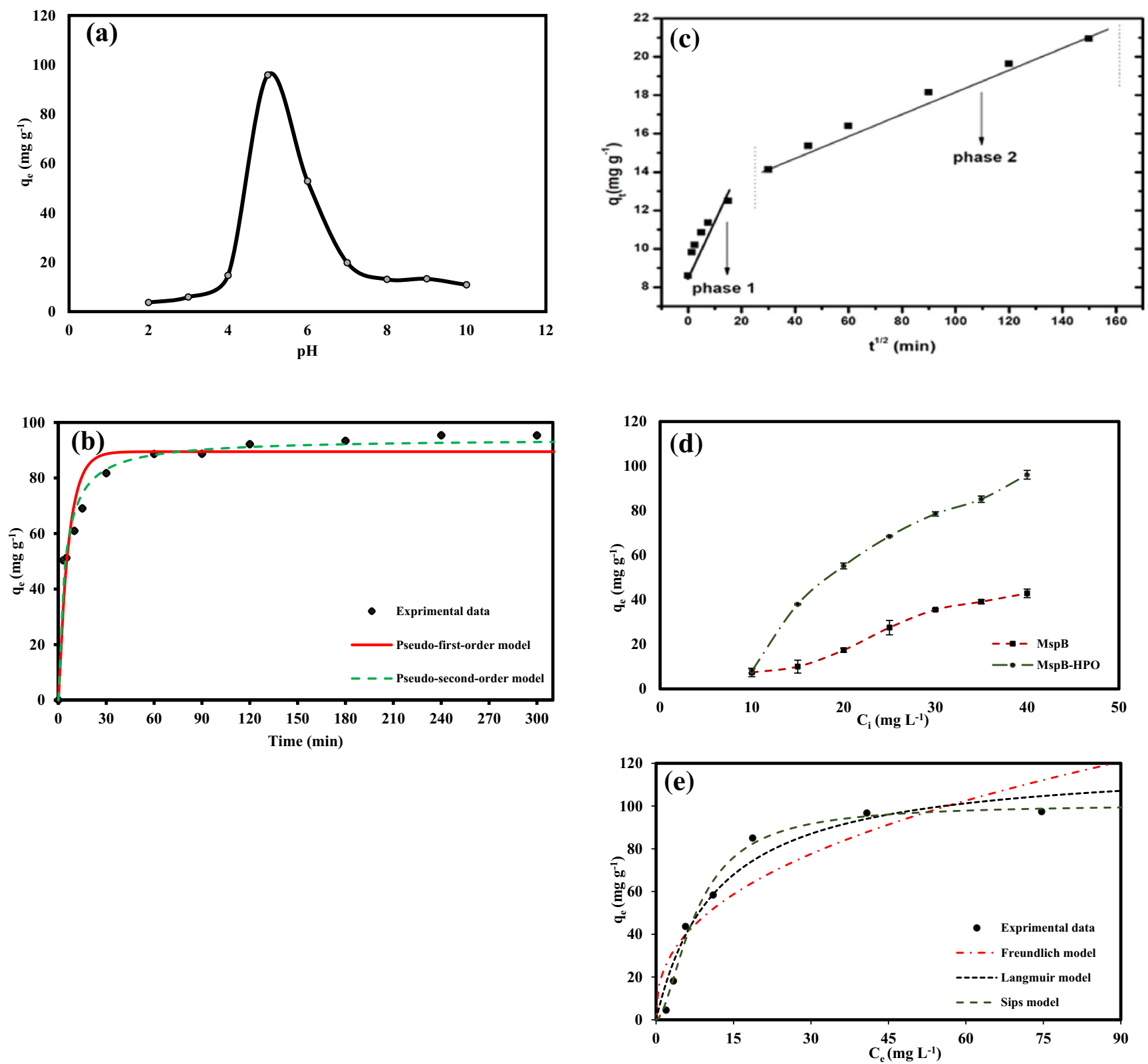

Fig. 3 a Effect of $\mathrm{pH}$ on adsorption of Dfc $\left(40 \mathrm{mg} \mathrm{L}^{-1}\right)$ by $\mathrm{MS}_{\mathrm{PB}}-\mathrm{HPO}$ $\left(0.4 \mathrm{~g} \mathrm{~L}^{-1}\right)$, b adsorption kinetic data modeling of Dfc $\left(40 \mathrm{mg} \mathrm{L}^{-1}\right)$ by $\mathrm{M}_{\mathrm{SP}} \mathrm{B}-\mathrm{HPO}\left(0.4 \mathrm{~g} \mathrm{~L}^{-1}\right)$, c intra-particle diffusion modeling, d

comparative adsorption of of Dfc $\left(10-40 \mathrm{mg} \mathrm{L}^{-1}\right)$ by $\mathrm{M}_{\mathrm{SP}} \mathrm{B}$ and synthesized $\mathrm{M}_{\mathrm{SP}} \mathrm{B}-\mathrm{HPO}\left(0.4 \mathrm{~g} \mathrm{~L}^{-1}\right)$, and $\mathbf{e}$ adsorption isotherm data modeling of Dfc $\left(2.5-100 \mathrm{mg} \mathrm{L}^{-1}\right)$ by $\mathrm{M}_{\mathrm{SP}} \mathrm{B}-\mathrm{HPO}\left(0.4 \mathrm{~g} \mathrm{~L}^{-1}\right)$

experiment was done using $40 \mathrm{mg} \mathrm{L}^{-1} \mathrm{Dfc}$ concentration and $0.4 \mathrm{~g} \mathrm{~L}^{-1}$ dose of $\mathrm{M}_{\mathrm{SP}} \mathrm{B}$ and studied from 1 to 300 min. The results (Fig. 3b) showed that the adsorption capacity increased rapid initially $(0-30 \mathrm{~min})$, then increased in a slow rate and then stabilized to reach equilibrium. At equilibrium, the unavailability of free active adsorption sites resulted in no further adsorption. Adsorption capacity and removal efficiency reached $95.383 \mathrm{mg} \mathrm{g}^{-1}$ and $83 \%$, respectively. Two kinetic models were used to evaluate the kinetic data as reported in other study (Iqbal et al. 2019).
Pseudo-first-order (PFO) model (Eq. (3)) (Ho 2004).

$q_{t}=q_{e}\left(1-e^{-k_{1 t}}\right)$

Pseudo-second-order (PSO) model (Eq. (4)) (Ho and Mckay 1999).

$\mathrm{q}_{\mathrm{t}}=\frac{\mathrm{k}_{2} \mathrm{q}_{\mathrm{e}}^{2} \mathrm{t}}{1+\mathrm{k}_{2} \mathrm{q}_{\mathrm{e}} \mathrm{t}}$

The intra-particle diffusion data was analyzed as reported elsewhere (Samiey 2015) using Eq. (5) which is written as 


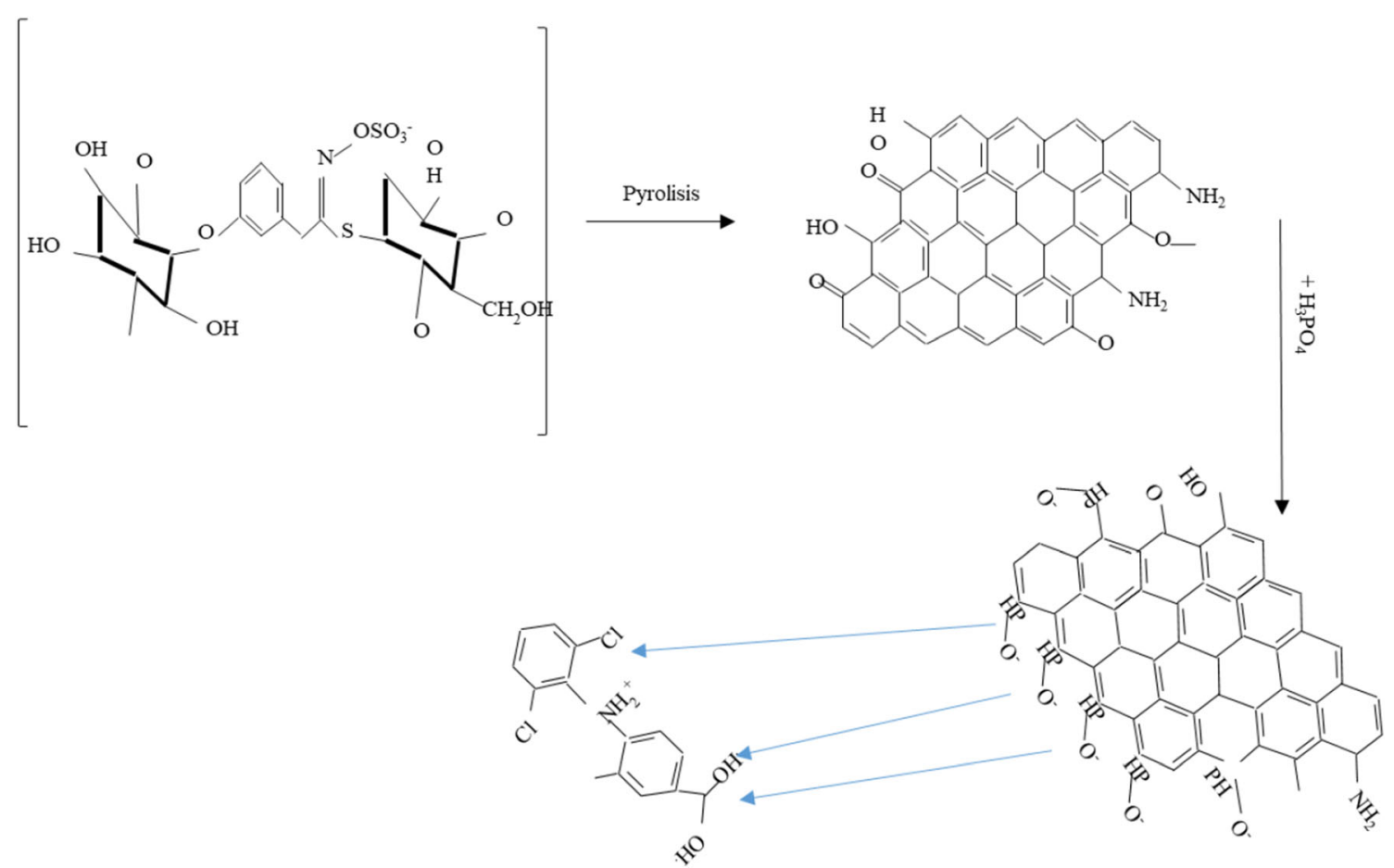

Fig. 4 Plausible reaction scheme of conversion of $\mathrm{M}_{\mathrm{SP}}$ (Jaja-chimedza et al. 2017) to biochar, negatively charged synthesized $\mathrm{M}_{\mathrm{SP}} \mathrm{B}-\mathrm{HPO}$ and adsorption of Dfc

$\mathrm{q}_{\mathrm{t}}=\mathrm{I}+\mathrm{k}_{\text {dif }} t^{0.5}$

where $q_{\mathrm{e}}$ and $q_{\mathrm{t}}$ are the adsorption capacity $\left(\mathrm{mg} \mathrm{g}^{-1}\right)$ at equilibrium and time $t(\mathrm{~min})$, respectively, and $k_{1}\left(\mathrm{~min}^{-1}\right)$ and $\mathrm{k}_{2}\left(\mathrm{~g} \mathrm{mg}^{-1} \mathrm{~min}^{-1}\right)$ represent rate constants of PFO, and PSO. I ( $\left.\mathrm{mg} \mathrm{g}^{-1}\right)$ is the intercept of the boundary layers thickness and $\mathrm{k}_{\text {dif }}\left(\mathrm{mg} \mathrm{g}^{-1} \min ^{-0.5}\right)$ is intraparticle diffusion rate constant.

The summary of adsorption kinetic data evaluated by the three models is presented in Table 2. The values of the model parameters suggest that the PSO model best fitted the kinetics data $\left(R^{2}=0.989\right.$; RMSE $\left.=3.554\right)$ compared to the other studied models. The differences in the experimental $\left(q_{\mathrm{e}}\right.$ exp $)$ and calculated maximum adsorption capacities $\left(q_{\mathrm{e}}\right.$ cal $)$ for the models used in the analysis also suggest that the PSO best fitted the adsorption kinetics. The fitting of the experimental data to the PSO kinetics model suggests a chemical process involving ionic exchanges between the $\mathrm{pH}$ modified Dfc and the $\mathrm{M}_{\mathrm{SP}} \mathrm{B}-$ HPO surface.

From the intra-particle diffusion modeling, the movement of the Dfc ions occurred in two different phases which were an initial rapid phase and a slow and stabilized phase as shown in Fig. 3c. These results suggest that diffusion was probably not the rate-limiting step but other factors may have control on the rate of adsorption (Yakout and Elsherif 2010; Abu-Danso et al. 2018).

\section{Dfc adsorption isotherm studies}

Different initial concentrations of Dfc (10 to $\left.40 \mathrm{mg} \mathrm{L}^{-1}\right)$ and its effect of on the adsorption was investigated with a constant amount of $\mathrm{M}_{\mathrm{SP}} \mathrm{B}-\mathrm{HPO}\left(0.4 \mathrm{~g} \mathrm{~L}^{-1}\right)$. The adsorption capacity of unmodified $\mathrm{M}_{\mathrm{SP}} \mathrm{B}$ was also examined simultaneously (Fig.

Table 2 Adsorption kinetics parameters and data of Dfc removal by $\mathrm{M}_{\mathrm{SP}} \mathrm{B}-\mathrm{HPO}$

\begin{tabular}{lll}
\hline Kinetic model & Parameter & Data \\
\hline Pseudo-first-order & $q_{\mathrm{e} \text { exp }}\left(\mathrm{mg} \mathrm{g}^{-1}\right)$ & 95.383 \\
& $q_{\mathrm{e} \mathrm{cal}}\left(\mathrm{mg} \mathrm{g}^{-1}\right)$ & 89.474 \\
& $k_{1}\left(\mathrm{~min}^{-1}\right)$ & 0.155 \\
& $\mathrm{RMSE}$ & 6.674 \\
& $R^{2}$ & 0.964 \\
Pseudo-second-order & $q_{\mathrm{e} \text { exp }}\left(\mathrm{mg} \mathrm{g}^{-1}\right)$ & 94.383 \\
& $q_{\mathrm{e} \text { cal }}\left(\mathrm{mg} \mathrm{g}^{-1}\right)$ & 94.206 \\
& $k_{2}\left(\mathrm{~g} \mathrm{mg}^{-1} \mathrm{~min}^{-1}\right)$ & 0.002 \\
& $\mathrm{RMSE}^{2}$ & 3.554 \\
& $R^{2}$ & 0.989 \\
Intra-particle diffusion & $q_{\mathrm{e} \text { exp }}\left(\mathrm{mg} \mathrm{g}^{-1}\right)$ & 94.383 \\
& $\mathrm{k}_{\text {dif }}\left(\mathrm{mg} \mathrm{g}^{-1} \mathrm{~min}^{-0.5}\right)$ & 3.161 \\
& $\mathrm{I}\left(\mathrm{mg} \mathrm{g}^{-1}\right)$ & 50.950 \\
& $\mathrm{RMSE}^{2}$ & 7.666 \\
& $R^{2}$ & 0.961 \\
\hline
\end{tabular}


$3 c)$. The results revealed that adsorption increased with an increase in Dfc concentration for both adsorbents. However, the removal capacity of $\mathrm{M}_{\mathrm{SP}} \mathrm{B}-\mathrm{HPO}$ was found to be two times higher than $\mathrm{M}_{\mathrm{SP}} \mathrm{B}\left(96.11 \mathrm{mg} \mathrm{g}^{-1}\right.$ and $\left.42.8 \mathrm{mg} \mathrm{g}^{-1}\right)$ at equilibrium adsorption which suggests that adsorption efficiency increased significantly after modification.

\section{Adsorption isotherm modeling}

Isotherm systems describe interaction between adsorbate and adsorbent. Overall, an isotherm curve demonstrates the phenomenon of the retention from the aqueous phase to a solid phase (Foo and Hameed 2010; Ahmed 2017). To analyze the experimental data, three isotherm models were used to elucidate how Dfc ions are adsorbed onto the surface of $\mathrm{M}_{\mathrm{SP}} \mathrm{B}$ HPO. The Sips model (Sips 1948) is a two-parameter model that combines characteristics of Freundlich and Langmuir models. The description of lower concentration adsorption isotherm data by the Sips model is similar to the Freundlich model and it occurs in a heterogeneous layer, whereas a monolayer adsorption takes place at higher adsorbate concentrations similar to the assumption of Langmuir model (Noori et al. 2017).

The Sips model is written as

$\mathrm{q}_{\mathrm{e}}=\frac{\mathrm{q}_{\mathrm{m}\left(\mathrm{K}_{\mathrm{s}} \mathrm{C}_{\mathrm{e}}\right)^{\mathrm{m}}}}{1+\left(\mathrm{K}_{\mathrm{s}} \mathrm{C}_{\mathrm{e}}\right)^{\mathrm{m}}}$

where $q_{\mathrm{e}}\left(\mathrm{mg} \mathrm{g}^{-1}\right)$ and $C_{\mathrm{e}}\left(\mathrm{mg} \mathrm{L}^{-1}\right)$ are the adsorption capacity and Dfc concentration at equilibrium time, respectively, $m$ is the exponent that is between 0 and 1 , and the Sips affinity is denoted by $\mathrm{K}_{\mathrm{S}}\left(\mathrm{L} \mathrm{mg}^{-1}\right)$.

Adsorption that follows Langmuir model occurs on definite adsorption sites by ions with similar equilibrium adsorption constants. The Langmuir model predicts monolayer adsorption (Langmuir 1918; Rathod et al. 2015). For an adsorption process that follows Langmuir model, the adsorbed ions are attached onto definite adsorption sites with similar energy. Langmuir model can be written as Eq. (7) (Langmuir 1918):

$\mathrm{q}_{\mathrm{e}}=\frac{\mathrm{q}_{\mathrm{mK}} \mathrm{C}_{\mathrm{e}}}{1+\mathrm{K}_{\mathrm{L}} \mathrm{C}_{\mathrm{e}}}$

where $K_{\mathrm{L}}\left(\mathrm{L} \mathrm{mg}^{-1}\right)$ is the Langmuir constant.

Freundlich model is an empirical model which describes interplay between multilayer and non-ideal sorption on a heterogeneous surface (Freundlich 1909; Rathod et al. 2015). The equation is defined as

$\mathrm{q}_{\mathrm{e}}=\mathrm{K}_{\mathrm{F}} \mathrm{C}_{\mathrm{e}}^{1 / \mathrm{n}}$

where $\mathrm{K}_{\mathrm{F}}\left(\mathrm{mg} \mathrm{g}^{-1}\right)$ is the Freundlich affinity constant and $n$ (g $\mathrm{L}^{-1}$ ) is the heterogeneity factor.

The modeled isotherm data are shown in Fig. 3d. The root mean square error (RMSE) and the correlation coefficients
$\left(R^{2}\right)$ obtained for the Sips model (2.842) and (0.993) as well as the Langmuir model (5.493) and (0.979), respectively, are presented in Table 3. The results suggest that the adsorption isotherm followed Sips and Langmuir models compared to the other studied model. This form of adsorption has been reported in other study (Zito et al. 2015). However, comparing the two models, a stronger correlation was found with the Sips model over the Langmuir although the process was studied under similar energy (room temperature). This phenomenon can likely be assigned to the mode of equilibrium adsorption determination at a single temperature by the two models since the parameters of determination vary between them. The results show that $\mathrm{M}_{\mathrm{SP}} \mathrm{B}-\mathrm{HPO}$ adsorbs Dfc as a monolayer; however, other adsorption surfaces were also available and contributed to the adsorption process, hence, the description by Sips model. This type of adsorption has been reported in other study (Daneshvar et al. 2018). The highest Sips adsorption capacity was found to be $100.876 \mathrm{mg} \mathrm{g}^{-1}$.

\section{Effect of co-existing cations}

The influence of co-existing cations on the Dfc removal by $\mathrm{M}_{\mathrm{SP}} \mathrm{B}-\mathrm{HPO}$ was studied in with 40,80 , and $160 \mathrm{mg} \mathrm{L}^{-1}$ concentrations of $\mathrm{Zn}^{2+}, \mathrm{Ca}^{2+}, \mathrm{Na}^{+}$, and $\mathrm{K}^{+}$cations in a constant Dfc (40 mg L $\left.{ }^{-1}(\mathrm{pH} \sim 5)\right)$ concentration. As shown in Fig. 5, $\mathrm{M}_{\mathrm{SP}} \mathrm{B}$-HPO's removal capacity for Dfc in the presence of these common cations generally decreased when the cation concentrations increased. The impact of the presence of $\mathrm{K}^{+}$ and $\mathrm{Zn}^{2+}$ strongly interfered with Dfc adsorption than the other studied cations. This trend of adsorption in which the adsorption capacity reduces in the presence of cations can be attributed to their chemical behavior. The presence of cations

Table 3 Isotherm model data for the removal of Dfe by $\mathrm{M}_{\mathrm{SP}} \mathrm{B}-\mathrm{HPO}$

\begin{tabular}{lll}
\hline Isotherm model & Parameter & Data \\
\hline Sips & $q_{\mathrm{e} e x p}\left(\mathrm{mg} \mathrm{g}^{-1}\right)$ & 97.406 \\
& $q_{\mathrm{e}}\left(\mathrm{mg} \mathrm{g}^{-1}\right)$ & 100.876 \\
$\mathrm{~m}$ & 0.586 \\
& $K_{\mathrm{S}}\left(\mathrm{L} \mathrm{mg}^{-1}\right)$ & 0.030 \\
& $R^{2}$ & 0.993 \\
& $\mathrm{RMSE}$ & 2.842 \\
Langmuir & $q_{\mathrm{e}}$ exp $\left(\mathrm{mg} \mathrm{g}^{-1}\right)$ & 97.406 \\
& $q_{\mathrm{m}}\left(\mathrm{mg} \mathrm{g}^{-1}\right)$ & 121.112 \\
& $\mathrm{~K}_{\mathrm{L}}\left(L \mathrm{mg}^{-1}\right)$ & 0.085 \\
& $R^{2}$ & 0.979 \\
& $\mathrm{RMSE}^{2}$ & 5.493 \\
Fruendlich & $\mathrm{K}_{\mathrm{F}}\left(\mathrm{mg} \mathrm{g}^{-1}\right)$ & 19.751 \\
& $\mathrm{n}\left(\mathrm{g} \mathrm{L}^{-1}\right)$ & 2.485 \\
& $R^{2}$ & 0.915 \\
& $\mathrm{RMSE}$ & 10.100 \\
\hline
\end{tabular}


Fig. 5 Effect of competing ions on Dfc $\left(40 \mathrm{mg} \mathrm{L}^{-1}\right)$ removal by $\mathrm{M}_{\mathrm{SP}} \mathrm{B}-\mathrm{HPO}\left(0.4 \mathrm{~g} \mathrm{~L}^{-1}\right)$

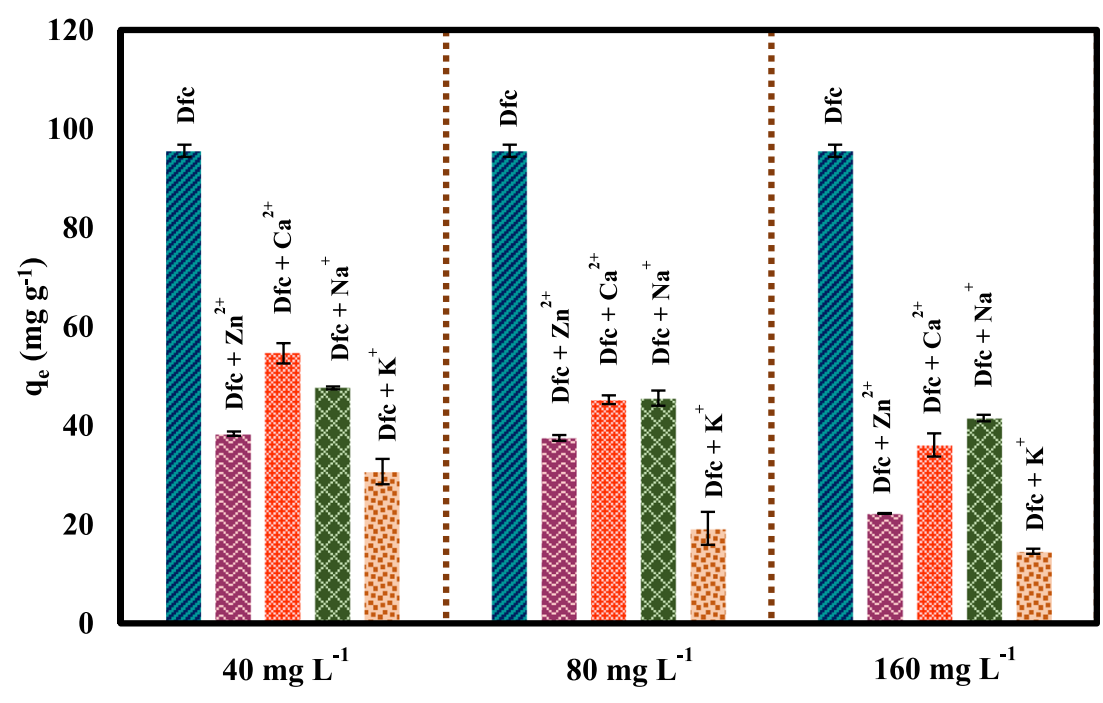

can result in a repulsion with Dfe which inhibit the mass transfer coefficient from the solution to the sorbent (Abudanso et al. 2019; Abujaber et al. 2019). On the other hand, the ionic strength of Dfc solution can decrease the adsorption capacity of $\mathrm{M}_{\mathrm{SP}} \mathrm{B}-\mathrm{HPO}$ through electrostatic interactions (Martinez-costa et al. 2018; Rafi et al. 2018). Moreover, when the concentration of cations was increased from 40 to $160 \mathrm{mg}$ $\mathrm{L}^{-1}$, the removal of Dfc decreased considerably.

\section{Regeneration of $\mathrm{M}_{\mathrm{SP}} \mathrm{B}-\mathrm{HPO}$}

Reusability of $\mathrm{M}_{\mathrm{SP}} \mathrm{B}-\mathrm{HPO}$ in repeated Dfc removal was studied using deionized $\mathrm{H}_{2} \mathrm{O}, 0.1 \mathrm{M} \mathrm{HNO}_{3}$, and $0.1 \mathrm{M} \mathrm{NaOH}$ during four regeneration cycles and the results are presented in Fig. 6 a and b. Reusability studies are conducted to test the resilience of the synthesized material and also save water treatment cost. The results showed that, after 4 cycles, the synthesized $\mathrm{M}_{\mathrm{SP}} \mathrm{B}-\mathrm{HPO}$ still had adsorption capacity $>100 \mathrm{mg} \mathrm{g}^{-1}$ under acidic condition (Fig. 6a). The limitation of the other used eluents in eluting the Dfc ions could be due to the unfavorable alkaline conditions because the Dfc was adsorbed in weak acidic conditions. Both adsorption and desorption trend in the study suggest that MSPB-HPO is regenerated reasonably after waste water treatment.

\section{Conclusions}

In this study, phosphate-modified Moringa seeds biochar $\left(\mathrm{M}_{\mathrm{SP}} \mathrm{B}-\mathrm{HPO}\right)$ was synthesized from Moringa oleifera seeds biochar $\left(\mathrm{M}_{\mathrm{SP}} \mathrm{B}\right)$ with phosphoric acid as the phosphate source. The synthesized $\mathrm{M}_{\mathrm{SP}} \mathrm{B}-\mathrm{HPO}$ was used for the removal diclofenac from aqueous medium. Different characterization techniques such as SEM, EDS, and FTIR were used to analyze both raw and the modified materials. The SEM image revealed that the synthesized $\mathrm{M}_{\mathrm{SP}} \mathrm{B}-\mathrm{HPO}$ was a porous material.
FTIR showed that $\left(\mathrm{P}-\mathrm{CH}_{3}\right)$ and $(\mathrm{P}-\mathrm{O})$ bonds appeared after modification. In addition, $\mathrm{pH}_{\mathrm{pzc}}$ showed the charge carried by the $\mathrm{M}_{\mathrm{SP}} \mathrm{B}-\mathrm{HPO}$ in acidic and basic media. The batch adsorption experiment results displayed the removal capacity of Dfc onto the $\mathrm{M}_{\mathrm{SP}} \mathrm{B}-\mathrm{HPO}$. The pseudo-second-order model could best describe the adsorption kinetics. Sips model compared to the other models described the isotherms data better, and the maximum Sips adsorption capacity was found to be
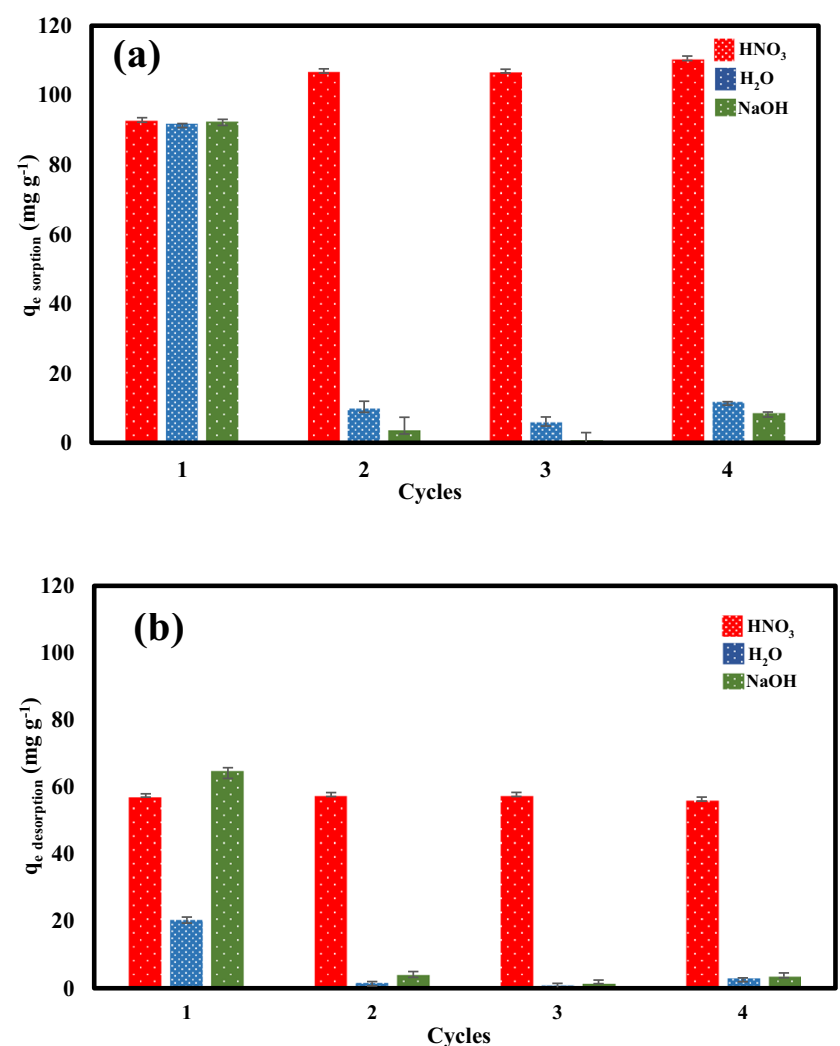

Fig. 6 Regeneration studies of Dfe removal by $\mathrm{M}_{\mathrm{SP}} \mathrm{B}-\mathrm{HPO}$ a adsorption and $\mathbf{b}$ desorption 
$100.876 \mathrm{mg} \mathrm{g}^{-1}$. The study showed that $\mathrm{M}_{\mathrm{SP}} \mathrm{B}-\mathrm{HPO}$ is recyclable for the removal of Dfc from aqueous environments.

Acknowledgments Open access funding provided by University of Eastern Finland (UEF) including Kuopio University Hospital. The authors thank Koen Silvius of Hogeschool van Arnhem en Nijmegen, Netherlands and Lenka Sunchankova for the help in some lab. experiments.

Funding information The Zayed University, Abu Dhabi, United Arab Emirates provided financial support (research cluster grant (R18029)).

Open Access This article is licensed under a Creative Commons Attribution 4.0 International License, which permits use, sharing, adaptation, distribution and reproduction in any medium or format, as long as you give appropriate credit to the original author(s) and the source, provide a link to the Creative Commons licence, and indicate if changes were made. The images or other third party material in this article are included in the article's Creative Commons licence, unless indicated otherwise in a credit line to the material. If material is not included in the article's Creative Commons licence and your intended use is not permitted by statutory regulation or exceeds the permitted use, you will need to obtain permission directly from the copyright holder. To view a copy of this licence, visit http://creativecommons.org/licenses/by/4.0/.

\section{References}

Abu-Danso E, Peräniemi S, Leiviskä T, Bhatnagar A (2018) Synthesis of $\mathrm{S}$-ligand tethered cellulose nanofibers for efficient removal of $\mathrm{Pb}(\mathrm{II})$ and Cd(II) ions from synthetic and industrial wastewater. Environ Pollut 242:1988-1997. https://doi.org/10.1016/J.ENVPOL.2018. 07.044

Abu-danso E, Bagheri A, Bhatnagar A (2019) Facile functionalization of cellulose from discarded cigarette butts for the removal of diclofenac pharmaceutical from water. Carbohydr Polym 219:46-55. https:// doi.org/10.1016/j.carbpol.2019.04.090

Abujaber F, Ahmad SM, Neng NR, Rodríguez Martín-Doimeadios RC, Guzmán Bernardo FJ, Nogueira JMF (2019) Bar adsorptive microextraction coated with multi-walled carbon nanotube phases - Application for trace analysis of pharmaceuticals in environmental waters. J Chromatogr A 1600:17-22. https://doi.org/10.1016/j. chroma.2019.04.035

Ahmed MJ (2017) Adsorption of quinolone, tetracycline, and penicillin antibiotics from aqueous solution using activated carbons : Review. Environ Toxicol Pharmacol 50:1-10. https://doi.org/10.1016/j.etap. 2017.01.004

Akhtar M, Hasany SM, Bhanger MI, Iqbal S (2007) Sorption potential of Moringa oleifera pods for the removal of organic pollutants from aqueous solutions. J Hazard Mater 141:546-556. https://doi.org/10. 1016/j.jhazmat.2006.07.016

Araujo LA, Bezerra CO, Cusioli LF et al (2018) Moringa oleifera biomass residue for the removal of pharmaceuticals from water. $J$ Environ Chem Eng 6:7192-7199. https://doi.org/10.1016/j.jece. 2018.11.016

Barczak M, Wierzbicka M, Borowski P (2018) Sorption of diclofenac onto functionalized mesoporous silicas: Experimental and theoretical investigations. Microporous Mesoporous Mater 264:254-264. https://doi.org/10.1016/j.micromeso.2018.01.013

Beyki MH, Mohammadirad M, Shemirani F, Saboury AA (2017) Magnetic cellulose ionomer/layered double hydroxide: An efficient anion exchange platform with enhanced diclofenac adsorption property. Carbohydr Polym 157:438-446. https://doi.org/10.1016/ j.carbpol.2016.10.017

Buildings K, Road M, Court E et al (1997) Characterisation and applications of activated carbon produced from Moringa Oleifera seed husks by single-step steam pyrolysis. Wat Res 31:759-766

Chen Y, Zhang X, Chen W, Yang H, Chen H (2017) The structure evolution of biochar from biomass pyrolysis and its correlation with gas pollutant adsorption performance. Bioresour Technol 246:101-109. https://doi.org/10.1016/j.biortech.2017.08.138

Coates J, Ed RAM, Coates J (2000) Interpretation of Infrared Spectra, A Practical Approach Interpretation of Infrared Spectra, A Practical Approach. 10815-10837

Coldebella PF, Fagundes-klen R, Valverde KC et al (2017) Potential Effect of Chemical and Thermal Treatment on the Kinetics, Equilibrium, and Thermodynamic Studies for Atrazine Biosorption by the Moringa oleifera Pods. Can J Chem Eng 95: 961-973. https://doi.org/10.1002/cjce.22756

Daneshvar E, Kousha M, Jokar M et al (2012) Acidic dye biosorption onto marine brown macroalgae : Isotherms, kinetic and thermodynamic studies. Chem Eng J 204-206:225-234. https://doi.org/10. 1016/j.cej.2012.07.090

Daneshvar E, Javad M, Malekzadeh A (2018) Versatile applications of freshwater and marine water microalgae in dairy wastewater treatment, lipid extraction and tetracycline biosorption. Bioresour Technol 268:523-530. https://doi.org/10.1016/j.biortech.2018.08. 032

de Carvalho HP, Huang J, Ni J, Zhao M, Yang X, Wang X (2015) Removal of Acid Black 1 and Basic Red 2 from aqueous solutions by electrocoagulation / Moringa oleifera seed adsorption coupling in a batch system. Water Sci Technol:203-213. https://doi.org/10. 2166/wst.2015.196

Foo KY, Hameed BH (2010) Insights into the modeling of adsorption isotherm systems. Chem Eng J 156:2-10. https://doi.org/10.1016/j. cej.2009.09.013

Freundlich H (1909) Kolloidchemie. Akademischer Verlagsgeselschaft, Leipzig.

Harvey OR, Herbert BE, Kuo L, Louchouarn P (2012) Generalized TwoDimensional Perturbation Correlation Infrared Spectroscopy Reveals Mechanisms for the Development of Surface Charge and Recalcitrance in Plant-Derived Biochars. Environ Sci Technol 46: 10641-10650

Ho Y-S (2004) Citation review of Lagergren kinetic rate equation on adsorption reactions. Scientometrics 59:171-177. https://doi.org/ 10.1023/B:SCIE.0000013305.99473.cf

Ho YS, Mckay G (1999) Pseudo-second order model for sorption processes. Process Biochem 34:451-465. https://doi.org/10.1016/ S0032-9592(98)00112-5

Hu X, Cheng Z (2015) Removal of diclofenac from aqueous solution with multi-walled carbon nanotubes modified by nitric acid is. Chin J Chem Eng 23:1551-1556. https://doi.org/10.1016/j.cjche. 2015.06.010

Iqbal J, Shah NS, Sayed M et al (2019) Synergistic effects of activated carbon and nano-zerovalent copper on the performance of hydroxyapatite-alginate beads for the removal of $\mathrm{As}^{3+}$ from aqueous solution. J Clean Prod 235:875-886. https://doi.org/10.1016/j. jclepro.2019.06.316

Jaja-chimedza A, Graf BL, Simmler C et al (2017) Biochemical characterization and anti- inflammatory properties of an isothiocyanateenriched moringa ( Moringa oleifera ) seed extract. PLOS 1:1-21. https://doi.org/10.7910/DVN/36WPXS

Jiang M, Yang W, Zhang Z et al (2015) Adsorption of three pharmaceuticals on two magnetic ion-exchange resins. J Environ Sci 31:226234. https://doi.org/10.1016/j.jes.2014.09.035

Jindo K, Mizumoto H, Sawada Y et al (2014) Physical and chemical characterization of biochars derived from different agricultural 
residues. Biogeosciences 11:6613-6621. https://doi.org/10.5194/ bg-11-6613-2014

Khorsand M, Dobaradaran S, Kouhgardi E (2017) Cadmium removal from aqueous solutions using Moringa oleifera seed pod as a biosorbent. Desalin Water Treat 71:327-333. https://doi.org/10. 5004/dwt.2017.20372

Langmuir I (1918) The adsorption of gases on plane surfaces of glass, mica and platinum. J Am Chem 40:1361-1403

Li Z, Yang P (2018) Review on Physicochemical, Chemical, and Biological Processes for Pharmaceutical Wastewater. IOP Conf Ser Earth Environ Sci 113. https://doi.org/10.1088/1755-1315/113/1/ 012185

Li L, Iqbal J, Zhu Y et al (2018) Chitosan/Ag-hydroxyapatite nanocomposite beads as a potential adsorbent for the efficient removal of toxic aquatic pollutants. Int J Biol Macromol 31:226-234. https:// doi.org/10.1016/j.ijbiomac.2018.09.190

Lonappan L, Rouissi T, Kaur S et al (2018) An insight into the adsorption of diclofenac on different biochars : Mechanisms, surface chemistry , and thermodynamics. Bioresour Technol 249:386-394. https://doi. org/10.1016/j.biortech.2017.10.039

Maina IW, Obuseng V, Nareetsile F (2016) Use of Moringa oleifera (Moringa) Seed Pods and Sclerocarya birrea (Morula) Nut Shells for Removal of Heavy Metals from Wastewater and Borehole Water. J Chem 2016:1-13. https://doi.org/10.1155/2016/9312952

Maria I, Manesco R, Vieira S, Fernandes M (2018) Removal of tartrazine from aqueous solutions using adsorbents based on activated carbon and Moringa oleifera seeds. J Clean Prod 171:85-97. https://doi.org/ 10.1016/j.jclepro.2017.09.237

Martinez-Costa J, Liva-ramos R, Padilla-Ortega E (2018) Sorption of diclofenac from aqueous solution on an organobentonite and adsorption of cadmium on organobentonite saturated with diclofenac. 66: 515-528. https://doi.org/10.1346/CCMN.2018.064119

Matouq M, Jildeh N, Qtaishat M et al (2015) The adsorption kinetics and modeling for heavy metals removal from wastewater by Moringa pods. J Environ Chem Eng 3:775-784. https://doi.org/10.1016/j. jece.2015.03.027

Moreno MM, Garidel P, Suwalsky M et al (2009) The membrane-activity of Ibuprofen, Diclofenac, and Naproxen: A physico-chemical study with lecithin phospholipids. Biochim Biophys Acta - Biomembr 1788:1296-1303. https://doi.org/10.1016/j.bbamem.2009.01.016

Murtaza B, Shah NS, Sayed M, Khan JA, Imran M, Shahid M, Khan ZUH, Ghani A, Murtaza G, Muhammad N, Khalid MS, Niazi NK (2019) Synergistic effects of bismuth coupling on the reactivity and reusability of zerovalent iron nanoparticles for the removal of cadmium from aqueous solution. Sci Total Environ 669:333-341. https://doi.org/10.1016/j.scitotenv.2019.03.062

Noori M, Al-musawi TJ, Ghahramani E et al (2017) Adsorption performance of magnesium / aluminum layered double hydroxide nanoparticles for metronidazole from aqueous solution. Arab J Chem 10: 611-623. https://doi.org/10.1016/j.arabjc.2016.07.003

Donald L. Pavia, Gary M. Lampman, George S. Kriz JAV (2009) Introduction to Spectroscopy, Cengage Learning.

Rafi M, Samiey B, Cheng C (2018) Study of Adsorption Mechanism of Congo Red on Oxide, Graphene Nanocomposite, Pamam. Materials (Basel) 11:1-24. https://doi.org/10.3390/ma11040496
Ramavandi B (2014) Treatment of water turbidity and bacteria by using a coagulant extracted from Plantago ovata. Water Resour Ind 6:36-50. https://doi.org/10.1016/j.wri.2014.07.001

Rathod M, Haldar S, Basha S (2015) Nanocrystalline cellulose for removal of tetracycline hydrochloride from water via biosorption : Equilibrium, kinetic and thermodynamic studies. Ecol Eng 84: 240-249. https://doi.org/10.1016/j.ecoleng.2015.09.031

Rutherford DW, Wershaw RL, Rostad CE, Kelly CN (2012) Effect of formation conditions on biochars : Compositional and structural properties of cellulose, lignin , and pine biochars. Biomass and Bioenergy 46:693-701. https://doi.org/10.1016/j.biombioe.2012. 06.026

Samiey B (2015) A New Approach for Analysis of Adsorption from Liquid Phase: A Critical Review. J Pollut Eff Control:3. https:// doi.org/10.4172/2375-4397.1000139

Sayed M, Gul M, Shah NS et al (2019) In-situ dual applications of ionic liquid coated $\mathrm{Co}^{2+}$ and $\mathrm{Fe}^{3+}$ co-doped $\mathrm{TiO}_{2}$ : Superior photocatalytic degradation of floxacin at pilot scale level and enhanced peroxidase like activity for calorimetric biosensing. J Mol Liq 282:275-285. https://doi.org/10.1016/j.molliq.2019.03.022

Shirani Z, Santhosh C, Iqbal J, Bhatnagar A (2018) Waste Moringa oleifera seed pods as green sorbent for efficient removal of toxic aquatic pollutants. J Environ Manage 227:95-106. https://doi.org/ 10.1016/j.jenvman.2018.08.077

Sips R (1948) On the Structure of a Catalyst Surface. J Chem Phys 16: 490-495. https://doi.org/10.1063/1.1746922

Souza B, Eyng E, Rodrigo P et al (2016) Flocculation associated with the extract of Moringa oleifera Lam as natural coagulant for the removal of reactive blue 5G dye. Acta Sci Electro 38:483-488. https://doi. org/10.4025/actascitechnol.v38i4.28796

Tavares FO, Adriane L, Pinto DM et al (2017) Environmentally friendly biosorbents (husks, pods and seeds ) from Moringa oleifera for $\mathrm{Pb}$ (II) removal from contaminated water. Environ Technol 38:31453155. https://doi.org/10.1080/09593330.2017.1290150

Tavengwa NT, Cukrowska E, Chimuka L et al (2016) Application of raw and biochared Moringa oleifera seed powder for the removal of nitrobenzene from aqueous solutions removal of nitrobenzene from aqueous solutions. Desalin Water Treat 57:25551-25560. https:// doi.org/10.1080/19443994.2016.1151381

Wang Y, Zuo S, Yang J, Yoon S (2017) Evolution of PhosphorusContaining Groups on Activated Carbons during Heat Treatment. Langmuir 33:3112-3122. https://doi.org/10.1021/acs.langmuir. $7 \mathrm{~b} 00095$

Wong S, Ngadi N, Inuwa IM, Hassan O (2018) Recent advances in applications of activated carbon from biowaste for wastewater treatment: A short review. J Clean Prod 175:361-375. https://doi.org/10. 1016/j.jclepro.2017.12.059

Yakout SM, Elsherif E (2010) Carbon - Sci. and Tech 1:144-153

Zito PF, Caravella A, Brunetti A et al (2015) Estimation of Langmuir and Sips Models Adsorption Parameters for $\mathrm{NaX}$ and $\mathrm{NaY}$ FAU Zeolites. Chem Eng J 60:2858-2868. https://doi.org/10.1021/acs. jced.5b00215

Publisher's note Springer Nature remains neutral with regard to jurisdictional claims in published maps and institutional affiliations. 